\title{
The concentration of mineral and total phosphorus in the coastal water of southeast coast of Lake Baikal
}

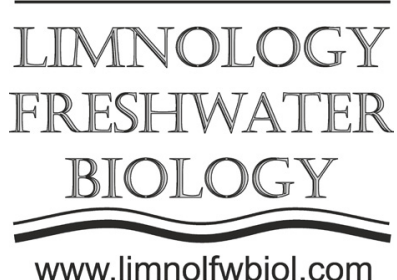

\author{
Eletskaya E.V., Tomberg I.V. \\ Limnological Institute, Siberian Branch of the Russian Academy of Sciences, Ulan-Batorskaya Str., 3, Irkutsk, 664033, Russia
}

\begin{abstract}
This work presents the results of the study of the phosphorus concentrations in the coastal water of the southeast coast of Lake Baikal. We have revealed that in May and September, the concentrations of total phosphorus in the coastal water do not exceed the values typical of mesotrophic water bodies. In July, the concentrations of total phosphorus in the coastal water near the Slyudyanka town as well as the Maksimikha and Enkhaluk settlements increase to the values corresponding to hypertrophic water bodies.
\end{abstract}

Keywords: Lake Baikal, mineral phosphorus, total phosphorus, eutrophication.

\section{Introduction}

At present, the problem of surface water pollution is the most relevant. An increase in the influx of nutrients leads to the excessive development of the biota and can be considered one of the indicators of the potential eutrophication (Timoshkin et al., 2016). Phosphorus is one of the most important nutrients for the growth and development of aquatic microorganisms in Lake Baikal. The phosphorus cycle in the water of the lake consists in the assimilation of its mineral forms (phosphates) by living organisms and the release of organic compounds in the forms of metabolic products as well as products of postmortem decomposition. During the subsequent mineralization of organic compounds, phosphates again enter the water (Krokhaleva and Chepil, 2017). However, recently, there has been an increase in the influx of phosphorus in Lake Baikal with wastewater and waters from tributaries, which leads to a significant increase in the productivity in the coastal waters.

Our study aimed to assess the dynamics of the concentration of mineral and total phosphorus in the littoral zone of the southeast coast of Lake Baikal.

\section{Materials and methods}

To assess the eutrophication processes in the littoral zone of Lake Baikal, from May to September 2019, we carried out studies along the southeast coast of Lake Baikal, from the Kultuk settlement to the UstBarguzin settlement. In the water samples collected at ten stations in the water's edge zone (1-3 m from the coast) and $100 \mathrm{~m}$ from the coast, the concentrations of phosphate (mineral) and total (gross) phosphorus were determined. The concentration of total phosphorus was determined in unfiltered water. After preliminary filtration, the concentrations of phosphate phosphorus were determined in the samples. Chemical analysis was carried out using conventional hydrochemical methods (Rukovodstvo..., 2009).

\section{Results and discussion}

The analysis of the obtained results revealed that in the coastal water of the lake, at the water's edge (Fig. 1A), the maximum concentrations of mineral phosphorus were recorded in May $(2-9 \mu \mathrm{g} P / 1)$. At the same time, the concentrations of total phosphorus varied from 11 to $49 \mu \mathrm{g} \mathrm{P} / \mathrm{l}$, which corresponds to the values for mesotrophic water bodies (Prakticheskaya gidrobiologiya..., 2006).

In July, the concentrations of mineral phosphorus decreased almost to zero due to its active consumption by phytoplankton and phytobenthos (Fig. 1B). However, the concentrations of total phosphorus increased in the coastal water of almost all stations. In the water from the water's edge zone near the Slyudyanka town as well as the Maksimikha and Enkhaluk settlements, the concentrations of total phosphorus in July corresponded to the concentrations for hypertrophic lakes and were $120 \mu \mathrm{g}$ P/l, $125 \mu \mathrm{g}$ P/l and $165 \mu \mathrm{g}$ P/l, respectively. At the same time, at the $100 \mathrm{~m}$ distance from the coast, the concentrations of total phosphorus mainly did not exceed $20 \mu \mathrm{g} / \mathrm{l}$. The exceptions were the concentrations near the Enkhaluk settlement ( $41 \mu \mathrm{g} \mathrm{P} / \mathrm{l})$, where there is a confluence of the Selenga River waters along the coast, and near the Maksimikha settlement (27 $\mu \mathrm{g} \mathrm{P} / 1)$, where an unfavourable ecological situation has been observed for several years (Timoshkin et al., 2016).

*Corresponding author.

E-mail address: lilitanna@lin.irk.ru (E.V. Eletskaya) 


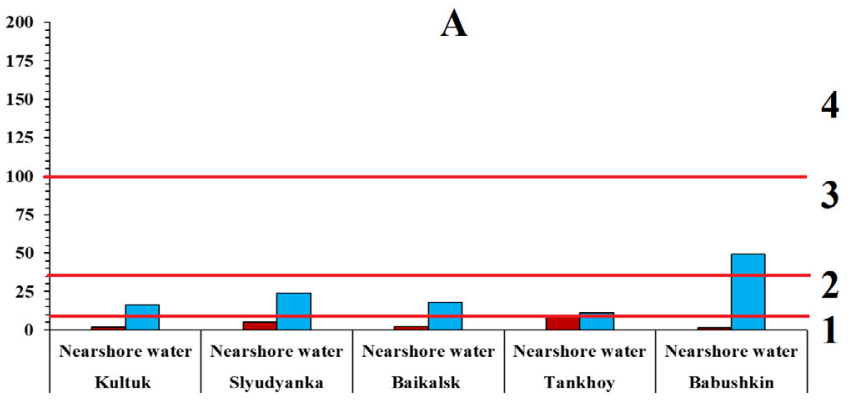

\section{1- Oligotrophic}

2- Mesotrophic

3- Eutrophic

4- Hypertrophic
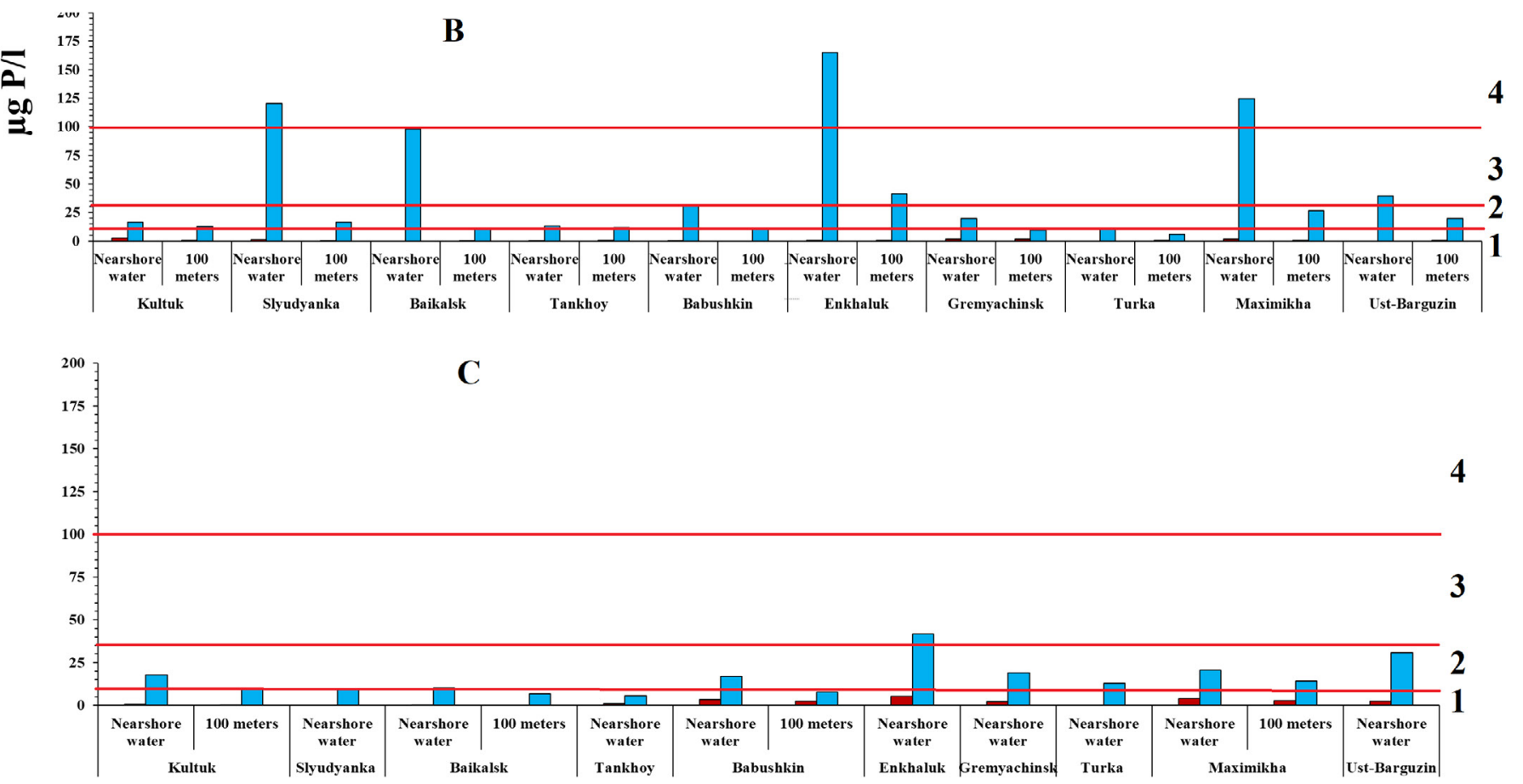

Fig.1. The concentrations of mineral and total phosphorus in the coastal water of the east coast of Lake Baikal in May (A), July (B) and September (C) 2019.

In September, due to the destruction of organic matter, the concentrations of mineral phosphorus in the coastal water (both at the water's edge and $100 \mathrm{~m}$ from the coast) mainly increased up to 3-5 $\mu \mathrm{g}$ P/1 (Fig. $1 \mathrm{C})$. The concentrations of total phosphorus during this period decreased to the minimum and varied at the water's edge from 6 to $19 \mu \mathrm{g}$ P/1. Its elevated values were recorded in the water from the water's edge zone near the Maksimikha (21 $\mu \mathrm{g}$ P/1), Ust-Barguzin (31 $\mu \mathrm{g}$ $\mathrm{P} / \mathrm{l}$ ) and Enkhaluk (42 $\mu \mathrm{g} \mathrm{P} / \mathrm{l}$ ) settlements, but they were much lower than the summer values. At the 100 $\mathrm{m}$ distance from the coast, the concentrations of total phosphorus in autumn did not exceed $14 \mu \mathrm{g} / 1$.

\section{Conclusions}

In the coastal water of the studied areas, the concentrations of mineral phosphorus do not exceed $9 \mu \mathrm{g}$ P/l in May and September and decrease to zeros in July. The concentrations of the total phosphorus in the water at the $100 \mathrm{~m}$ distance from the coast in most areas of the southeastern part of the lake in July corresponds to the values typical of mesotrophic water bodies, and in October, their values decrease to the values of oligotrophic water bodies. In the coastal water, the concentrations of total phosphorus in all studied months also correspond to the concentrations of mesotrophic water bodies. The exceptions are the areas of the Slyudyanka town as well as the Enkhaluk and Maksimikha settlements, where in July, the concentrations of total phosphorus in the coastal water reach the values of hypertrophic water bodies.

This study was carried out within the framework of the state task topics Nos. 0345-2016-0009 "Largescale changes in the ecology..." and 0345-2016-0008 "Assessment and forecast of the ecological state of Lake Baikal...".

\section{References}

Krokhaleva S.I., Chepil A.P. 2017. The phosphorus concentrations in water bodies of the city of Birobidzhan. Vestnik Priamurskogo Gosudarstvennogo Universiteta imeni Sholom-Aleykhema [Bulletin of the Sholom-Aleykhem Amur State University] 3 (28): 47-55. (in Russian)

Prakticheskaya gidrobiologiya. Presnovodnyye ekosistemy [Practical Hydrobiology. Freshwater ecosystems]. In: Fyodorov V.D., Kapkov V.I. (Eds.). Moscow: PIM. (in Russian) 
Rukovodstvo pokhimicheskomu analizu poverkhnostnykh vod sushi. Chast' 1 [Guidelines for the chemical analysis of land surface waters. Part 1] 2009. In: Boeva L.V. (Ed.). Rostov on Don: NOK. (in Russian)

Timoshkin O.A., Samsonov D.P., Yamamuro M. et al. 2016. Rapid ecological change in the coastal zone of Lake Baikal (East Siberia): is the site of the world's greatest freshwater biodiversity in danger? Journal of Great Lakes Research 42(3): 487-497. DOI: 10.1016/j.jglr.2016.02.011 